\title{
Endoscopic Treatment for Anastomotic Varices after Choledochojejunostomy
}

\section{Takahiro Sato*}

Department of Gastroenterology, Sapporo Kosei General Hospital, Sapporo, Japan

"Corresponding author: Takahiro Sato, MD, Department of Gastroenterology, Sapporo Kosei General Hospital, Kita 3 Higashi 8, Chuo-ku, Sapporo 060-0033, Japan, Tel: +81 11261 5331; Fax: +81 11261 6040; E-mail: taka.sato@ja-hokkaidoukouseiren.or.jp

Rec date: June 27, 2016; Acc date: June 29, 2016; Pub date: July 07, 2016

Copyright: @ 2016 Sato T et al. This is an open-access article distributed under the terms of the Creative Commons Attribution License, which permits unrestricted use, distribution, and reproduction in any medium, provided the original author and source are credited.

\section{Introduction}

Ectopic varices are defined as portosystemic venous collaterals occurring anywhere in the gastrointestinal tract other than the esophagogastric region. Anastomotic varices after choledochojejunostomy should be considered when evaluating gastrointestinal hemorrhage in patients with previous surgery and mesenteric venous hypertension. Hemorrhaging from varices in the jejunal loop [1], with extrahepatic portal vein obstruction after choledochojejunostomy, is a rare condition but several articles have been published. Various medical treatments, such as interventional radiology and surgery, have been used to control bleeding from anastomotic varices after choledochojejunostomy; however, there is no best treatment strategy for anastomotic varices. Anastomotic varices after choledochojejunostomy drain directly into the intrahepatic portal vein. Therefore, endoscopic treatment is difficult for this condition and endoscopic obliterative therapy with N-butyl-2-cyanoacrylate is the preferred treatment for this type varices $[1,2]$.

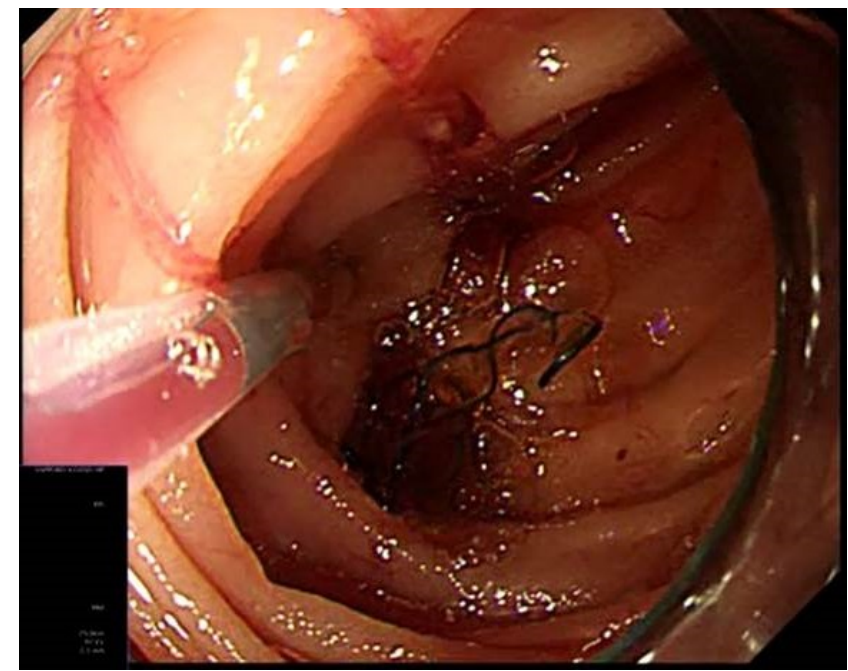

Figure 1a: Endoscopic obliterative therapy with N-butyl-2cyanoacrylate for anastomotic varices (case 1).

Endoscopic obliterative therapy was successfully performed for two anastomotic variceal patients after choledochojejunostomy with a high concentration of N-butyl-2-cyanoacrylate (Histoacryl [2], B.Braun Dexon GmbH Spangenberg, Germany) (Figures 1a-2b).

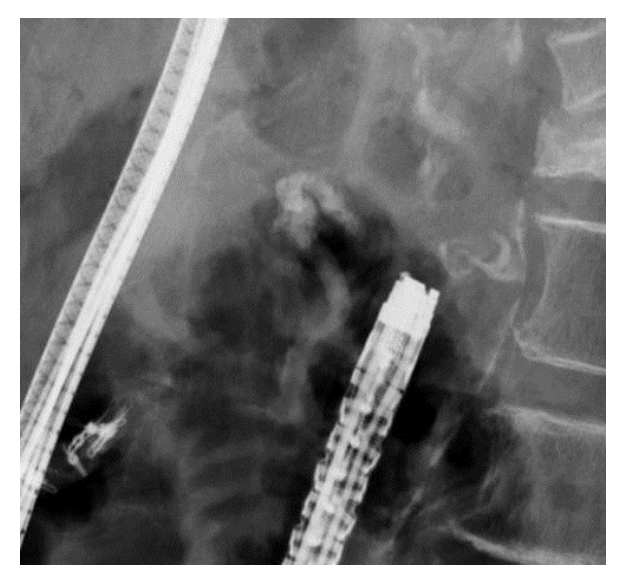

Figure 1b: Fluoroscopic observation with an infusion of n-butyl-2cyanoacrylate to determine the extent of the varices (case 1).

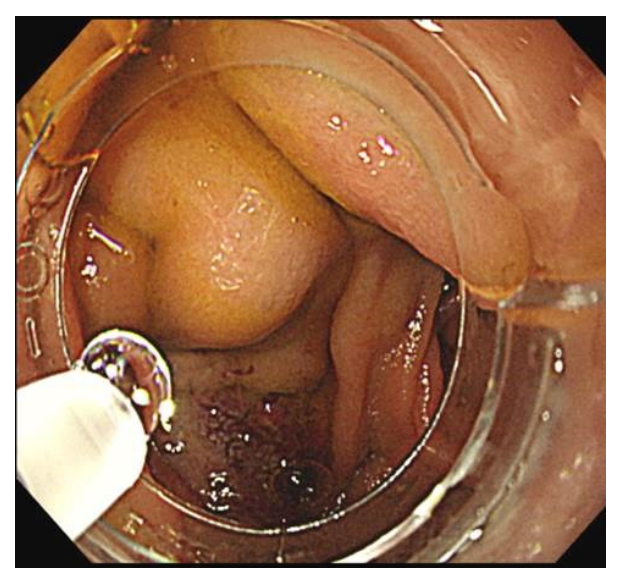

Figure 2a: Endoscopy revealed large, coil-shaped varices in the afferent jejunal loop(case 2).

For endoscopic obliterative therapy of anastomotic varices, we used $\mathrm{N}$-butyl-2-cyanoacrylate diluted to a final concentration of $83 \%$ in $5 \%$ Lipiodol (Guerbert, Roissy, France). Lipiodol prevents the tissue adhesive from polymerizing too quickly and also allows for radiographic monitoring. 
Citation: Sato T (2016) Endoscopic Treatment for Anastomotic Varices after Choledochojejunostomy. J Liver 5: i103. doi: 10.4172/2167-0889.1000i103

Page 2 of 2

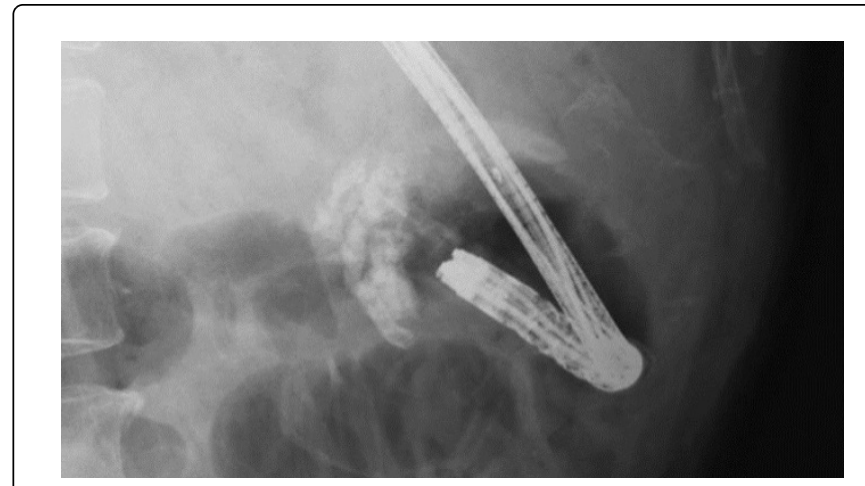

Figure 2b: Fluoroscopic findings of endoscopic obliterative therapy with $\mathrm{N}$ butyl-2-cyanoacrylate for anastomotic varices (case 2).
Endoscopic obliterative therapy with a high concentration of $\mathrm{N}$ butyl-2-cyanoacrylate is useful for patients with anastomotic varices after choledochojejunostomy.

\section{References}

1. Gubler C, Glenck M, Pfammatter T, Bauerfeind P (2012) Successful treatment of anastomotic jejunal varices with $\mathrm{N}$-butyl-2-cyanoacrylate (Histoacryl): single-center experience. Endoscopy 44: 776-779.

2. Deepak KB, Sharma BC, Sriram PVJ (1999) Endoscopic management of bleeding ectopic varices with Histoacryl. HBP Surg 11: 171-173. 